\title{
Exploring the Concept of Leadership Derailment: Defining New Research Agenda
}

\author{
Benjamin James Inyang ${ }^{1}$ \\ ${ }^{1}$ Department of Business Management, University of Calabar, Calabar, Nigeria \\ Correspondence: Benjamin James Inyang, Department of Business Management, University of Calabar, Calabar, \\ Nigeria. Tel: 234-803-377-3403. E-mail: benji1955.unical@yahoo.co.uk
}

Received: May 18, 2013

Accepted: July 1, 2013

Online Published: July 16, 2013

doi:10.5539/ijbm.v8n16p78

URL: http://dx.doi.org/10.5539/ijbm.v8n16p78

\begin{abstract}
Leadership is a process of influencing people to work towards the attainment of organisational goals. For many decades leadership research tended to take a one-sided view, emphasizing the positive and constructive aspects and very little written about the dark side of leadership-leadership derailment. The recent corporate failures and scandals and the 2008 economic crises were not unconnected with leadership failures. A consideration of the dark side of leadership is likely to increase our knowledge and ability to develop effective leaders needed for the twenty-first century. The paper seeks to explore the dark side of leadership as an important aspect of the total leadership concept; to identify the causes, consequences of and strategies for managing derailment; and to define the direction of research agenda in this relatively unexplored area. The paper adopted a qualitative survey method and this facilitates in-depth, critical and contextual analysis of available mainstream literature. A review of the paltry literature provided the basis for defining the research agenda for the dark side of leadership. Leadership derailment was found to be pervasive in organisations and this arose from leadership, followership and situational/environmental factors. The observed consequences included; low staff morale, low productivity, inhibition of leader's career progression and loss of organisational reputation. Remedies advocated to avoiding leadership derailment included: executive coaching, development assignments, systematic feedback and self-awareness, among others.
\end{abstract}

Keywords: leadership derailment, executive derailment, self-awareness, executive coaching, systematic feedback, leadership training

\section{Introduction}

The concept of leadership is not easily amenable to a universal definition as many scholars are wont to consider it from their individual perspectives. Hogan and Kaiser (2005:172) define leadership as "the ability to build and maintain a group that performs well relative to its competition". The yardstick for evaluating leadership of a group over time is how well the group performs in terms of valued outcomes. Inyang (2004:121) considers leadership as process which "involves the use of non-coercive influence to shape a group's or organization's goals, motivate behavior towards the achievement of those goals and help define group or organization culture". By extension leadership is a process of influencing people so that they strive willingly and enthusiastically toward the realization of group goals. A common denominator in leadership definition is the emphasis on an individual taking charge of a group and organizing members toward the attainment of valued goals which have been determined a priori.

Leadership is one of the most researched topics in management and organization literature. Hogan and Kaiser (2005) see leadership as a real and vastly consequential phenomenon and probably the single most important issue in the human sciences. The focus of leadership research is apparently skewed to such issues as leadership effectiveness, identifying the characteristics of successful leaders, leadership theories and developing leaders. Hogan and Kaiser (2005) aptly note that generally, leadership research tended to take a rather one-sided view on leadership, emphasizing its positive and constructive aspects while avoiding its dark side. A possible explanation or reason for this one-sided treatment of leadership may well be "that leadership research has primarily focused on leader effectiveness and those factors contributing to optimal performance and results" (Glaso, Einarsen, Mathiesen and Skogstad, 2010:3)

Very little is written about leadership derailment or leadership failure. Derailment is used as a metaphor of a 
train coming off the track. The train derailment is usually unintentional, resulting into considerable damage to both the individual and the organization. Fulmer and Conger (2004) note that leadership has been studied for over 50 years and over 15,000 articles and books published on the topic with organizations spending an estimated $\$ 50$ billion a year to develop leaders. Very recently, Furnham (2010a) notes that the many decades of leadership study has produced over 50,000 books with 'leadership' in their title but almost none on leadership derailment or failure, which he considers "the elephant in the boardroom". Furnham (2010a:4) in his seminal publication also notes that "more leaders fail and derail than become successes. Yet the emphasis in the literature seems also to have been on the minority of good or great leaders". McGregor (2005:1) succinctly captures this situation when he notes that:

We live in a world where organizational failure is endemic - but where frank, comprehensive dissections of those failures are still woefully infrequent; where success is too easily celebrated and failures are too quickly forgotten; where short-term earnings and publicity concerns block us from confronting - much less, learning from - our stumbles and our blunders.

Thus the dark side of leadership is often ignored in the literature as "a place inhabited by incompetence, flawed character and unethical behavior" (Slattery, 2009:1).

The scenario of lack of research output is continuing despite the fact that leadership derailment and by any other nomenclature - leadership failure, executive derailment, bad leadership, and managerial incompetence - is a pervasive phenomenon in organizational life. Leadership derailment represents a significant development challenge for employees and it is a major concern for corporate organizations desirous of managing the risk of leadership failure. The recent spate of corporate failures, scandals and bankruptcies in corporate American, Europe and elsewhere were not unconnected with failed leadership. The world economic crises of 2008/2009 point to the fact that the personalities of individual leaders tended to override business strategy leading to the colossal corporate failure. Previously successful leaders derailed and failed and failed their organizations causing untold hardship to stakeholders.

The one-sided treatment of leadership emphasizing the positive aspects without corresponding consideration of the dark side has the effect of limiting our knowledge about the phenomenon of the leadership. Hogan, Raskin and Fazzini (1990), note that when the dark side is ignored, we have incomplete knowledge and understanding of leadership. According to Burke (2006:98) "A consideration of the dark side of leadership is likely to increase our ability to effectively develop the leaders organizations will need in the twenty-first centuries".

The three-fold objectives of this paper are:

1) To explore the dark side of leadership - leadership derailment as an important aspect of the leadership concept to gain complete knowledge about leadership.

2) To identify the causes, consequences of and strategies for managing derailment.

3) To define the direction of research in this relatively unexplored area.

The paper is divided into eight sections. The introductory section is followed by the literature review which explores the concept of leadership derailment while section three states the research methodology. Section four identifies the causes of leadership derailment followed by section five which considers the consequences of the dark side of leadership. Section six is concerned with developing strategies to prevent derailment while section seven defines the research agenda. This is followed by the conclusion.

\section{Literature Review: Exploring Leadership Derailment}

Leadership derailment is a concept that has been given different connotations in the literature. A representative view from the scanty literature shows that scholars tended to apply different nomenclatures to describe the phenomenon of leadership derailment or leaders who fail. Furnham (2010a) aptly notes that the work on leaders who fail is marked by different terms and he presents a checklist of ten words scholars used in this area.

1) Aberrant (leader) - abnormality, atypicality and deviance.

2) Anti-social (leaders) - psychopath, immoral, delinquent.

3) Dark side (Traid) (leaders) - evil, dismal and menacing.

4) Derailed (leaders) - thrown off course.

5) Despotic (leaders) - autocratic.

6) Destructive (leaders) - ruining, spoiling. 
7) Incompetent (leaders) - inadequate, ineffective, unqualified.

8) Malignant (leaders) - doing harm, spreading malevolence.

9) Toxic (leaders) - poisonous.

10) Tyrannical (leaders) - arbitrariness, oppressive, unjust.

Furnham (2010a) roughly categorized these terms into three classes of leaders.

1) Bad leaders (dark side, despotic, destructive, malignant, toxic and [destructive] which implies the behavior is evil, amoral, unjust.

2) Sad leaders (incompetent) which implies that these leaders simply do not have the skills or abilities for the job.

3) Mad leaders (aberrant, anti-social, derailed) which implies that the leaders are mentally unstable or psychologically maladjusted.

Leslie and Van Velsor (1996) use the term leadership failure which is conceptualized in the context of career derailment. Following from this conceptualization Burke (2006:91) considers derailment in leadership or executive role "as being involuntarily plateaued, demoted or fired below the level of expected achievement or reaching that level but unexpectedly failing".

Jones and Lewis (2005:3) use the term executive derailment to refer to a situation where "executives are successful up to a point in their careers, yet they unintentionally failed". Jones and Lewis (2005) also note the outcomes of executive derailment to include the executive being demoted, terminated, plateaued or ignored and assigned in a "dead end" job, forced into early retirement, or even worse, arrested and prosecuted. Henderson (2010) similarly considers executive derailment as a situation when an executive or senior leader plateaus in his leadership role due to fatal flaws that led to his/her downfall.

Managerial derailment is also used to describe leadership failure and this simply refers to reasons why people in positions in the organizations have difficulties building teams or achieving results through others. Similarly, managerial incompetence which describes a person's inability to build successful team that is able to achieve results through others as been used in the literature. Hogan and Kaiser (2005:175) conceptualize managerial incompetence "in terms of not having the characteristics needed for success, that is, too little of the right stuff". Furnham (2010b) considers the concept of management failure which occurs when the person who is appointed to do a job fails to deliver the set objectives, often with dire consequences.

Another concept that has emerged in the literature is ineffective leadership which Schilling (2009) refers to those behaviors of leaders that are counterproductive to organizational success. Ineffective leaders are therefore described as leaders with ineffective character flaws and who are unable to manage their emotions and develop and maintain satisfactory interpersonal relationships (Pienaar, 2011). Such leaders are not able to achieve valued outcomes for the organization leading to its downfall.

Einarsen, Aasland and Sogstad (2007) identify with the concept of destructive leadership which they defined as "The systematic and repeated behaviour by a leader, supervisor or manager that violates the legitimate interest of the organization, by undermining and/or sabotaging the organization's goals, tasks, resources and effectiveness, and/or the motivation, well-being or job satisfaction of subordinates" (p. 208). This definition highlights ongoing leader's behaviour as major influence over outcomes for both the organization and followers. On his part, Slattery (2009) considers the 'dark side of leadership' which he defines as "an ongoing pattern of behavior exhibited by a leader that results in overall negative organizational outcomes based on the interactions between the leader, follower and the environment" (p. 4). The author sees the organizational goals, morale and follower satisfaction as being thwarted by the leader's misuse of power and his self-interest.

Leadership derailment represents significant challenges for corporate organizations desirous of achieving corporate outcomes that drive competitive advantage in a highly competitive business environment. Derailment had untold consequences for the leader, employees and organization. Webber (1998) sees leadership derailment as occurring when a leader who had the ability and opportunity to accomplish more, suddenly ends up fired or demoted or simply fails to succeed at the level for which he was promoted or called to perform. Bourne and MacKinnon (n.d.) note that leadership derailment occurs in a situation when leaders who progress 'up the ladder' capitalizing on their key strengths suddenly fail to develop more widely and being unable to deliver results when confronted by challenges that require a broader range of capabilities.

Leadership derailment therefore occurs because there is a disconnect between the skills and competencies of the leaders and the requirement of the new and higher job responsibility leaders are saddled with. The recent 
corporate failures in the different parts of the world are caused to a very great extent, by failed leadership in former successful organizations. The ongoing talent war and increased competitive pressures place more demands for higher quality leadership in organization. Organizational leaders are more and more been scrutinized or assessed on their leadership performance. There is obvious rationale to study leadership from both sides - leadership successes and leadership failures (the dark side) - to gain better and complete knowledge of leadership. The quest for this complete understanding informed this study.

\section{Methodology of Study}

The paper adopted a qualitative literature survey method involving secondary sources of data collection. This method facilitates in-depth, critical and contextual analysis of available mainstream literature. A survey of the paltry literature provided insight about the significant issues of leadership derailment. This methodology also provided the basis for gaining a deeper understanding and defining the research direction and agenda of the dark side of leadership, which has apparently remained underexplored for decades despite reported cases of the colossal corporate failures in recent times in the different parts of the world.

\section{Causes of Leadership Derailment}

The causes of leadership derailment are multi-faceted and are excoriated through combination of behavioural, organizational and situational factors which seriously impact on organization outcomes. Leadership derailment is therefore best considered as a product of the interaction among the leader, the people being led and the situation or environmental dynamics under which the leader is challenged to lead the organization or unit to success.

Ashford (1994) argues that leaders who frequently engage in a range of behaviours such self-aggrandizement; belittling of followers, lack of consideration for others, forcing styles of conflict resolution; punishment for no apparent reason and discouraging initiative, undermine organizational goals and the well-being of followers. Schilling (2009) notes that these leaders also exhibited behaviours that were aimed at personal gratification rather than achieving organizational goals. In the same vein, Higgs (2009) identifies four themes to the dark side of leadership behaviors which include abuse of power; inflicting damage on others; over exercise of control and rule-breaking to satisfy personal needs. Hogan (1994) notes that leaders who are associated with such behaviors are pressured by their followers and considered as untrustworthy, overly ambitious and disingenuous.

The behaviors of followers and situational factors or environmental dynamics are known to also cause leadership derailment. This is usually the case when followers lack self-esteem, engaged in power games, idealize the leader or have unmet psychological needs (Conger, 1990; Padilla, Hogan and Kaiser, 2007). Padilla et al., (2007) argue that when the interaction of the leader and follow is supported by a conducive environment it can lead to organizational decline or destruction.

Mackie (2008) identifies two contrasting approaches to the classification of derailment.

a) The personality approach which attempts to describe maladaptive personality trait that when combined with the right environmental catalyst can cause leadership derailment and reduced performance in the organization.

b) The organizational approach which classifies business challenges like mergers and acquisitions as predisposing leaders to derailment.

The Center for Creative Leadership (CCL) (www.ccl.org) has since the 1980s through series of studies extensively researched on the issues of successful and unsuccessful leaders. CCL defines a successful leader as one who makes it to at least a senior leadership level and is considered as having the potential for promotion by senior executives. By contrast, a derailed leader makes it to that same level but plateaus due to a disconnect or lack of fit between personal characteristics and the skills and demands of the job. Although both successful and derailed leaders shared many of the same skills and flaws, those who remained successful share five common characteristics:
1) Diversity in their career paths.
2) Maintained composure under stress.
3) Handle mistakes with poise.
4) Focused problems-solvers; and
5) Got along with all kinds of people. 
Leaders who derail have five key characteristics.

1) Difficulty in changing or adapting - resistant to change, learning from mistakes and developing.

2) Problems with interpersonal relationship - difficulties in developing good working relations with others.

3) The failure to build and lead a team - difficulties in selecting and building a team.

4) Failure to meet business objectives - difficulties in following upon promises and completing jobs.

5) Having too narrow a functional orientation - lacks depth to manage outside of one's current function.

Leslie and Van Velsor (1996) similarly identify four causes of leadership derailment to be:

1) Poor interpersonal skills, that is, being insensitive, arrogant, cool, aloof, and overly ambitious.

2) Unable to get work done, that is, betraying trust not following through.

3) Unable to build a team, that is, being unable to develop a team.

4) Unable to make the transition after a promotion.

Ready (2005) in a 32-company study around the world identifies seven key reasons why leaders fail to lead in their organizations.

a) Poor stakeholder management: Executive derailment was found to be attributed to the fact that leaders are unable to manage interdependencies as they advance in their careers. These interdependencies or stakeholders might take the form of other senior executive personnel within the group, team members, suppliers, customers, regulators, the media and a host of other players who need to be influenced so that the leader can shape and implement his agenda effectively.

b) Failing to balance diversity and alignment among the top team: This concerns the leader's inability to manage top team effectively, reconcile the tensions between nurturing diverse perspectives that create edge and vitality and bringing about the alignment needed to craft, articulate and execute enterprise strategy.

c) Flawed execution of articulated strategy: This factor of executive derailment is due to the inability of the leader to deliver value and results according to the articulated enterprise strategy.

d) An insufficient mass of followership: Effective leadership is a product of the interactions among the leader, the followers and the organization's context. The respondents identified "critical mass of fellowship" as factor of leadership failure. If executives fail to engage their employees and fail to inspire them to feel central to their organization's success then they have fundamentally fail to build the foundation for their leadership.

e) A poor capacity for listening: A leader who fails to listen to his followers may experience isolation, which will eventually lead to derailment.

f) An inability of reinventing during large scale change: Failure may result from the leader's lack of interest or capacity to reinvent one's leadership style when such changes are evidently required during organizational transformation efforts.

g) A poor fit with the company's core values: Senior executives derail when they fail to lead within the bounds of their company's values. The values of the company serve as the foundation for its core identity and therefore when leaders act outside these guiding principles they are likely to derail.

A critical analysis of the derailment dynamics shows that a leader's early strength can become a weakness later in his career. The same skills and competencies that enable a leader to succeed in his early career may sometimes become liabilities at the later date when the leader progresses to higher job positions and cannot develop new skills to handle or match the new job demands.

\section{Consequences of Leadership Derailment}

Derailment draws on the metaphor of a train coming off tract and often resulting in serious injuries to the occupants, train and the action-point of the incident. Leadership derailment has adverse consequences for the entire organizational systems. Wan (2011) sees these consequences to include the inability of meeting organizational outcomes, the loss of organizational reputation, breeding of dysfunctional and irresponsible or unethical behaviours, as well as the decreased psychological well-being of those adversely affected by derailed leaders or managers.

The follower or employee whose psychological well-being is affected by leadership derailment becomes demoralized and disengaged and therefore less productive in the organization. McGraw-Hill Answers (n.d.) 
notes that the dark sides of personality traits "are irritating, counterproductive behavioural tendencies that interfere with a leader's ability to build cohesive teams and cause followers to exert less effort toward goal accomplishment" (p.9). Leadership derailment equally inhibits the leader's ability to progress in his career and this may even result in his demotion or even being fired for failure to perform to expectations.

Other consequences associated with such negative workplace behavior - derailment - are according Slattery (2009) bullying, harassment, conflict, theft and unethical behavior in the organization. The organization is likely to experience increased employee turnover (talent loss) as well as missed business opportunities and to remain competitive. There are also the replacement costs that will be involved when the organization recruits new employees to replace the derailed managers.

Leadership derailment therefore has dire consequences for the individuals as followers, the derailed leader, organization and stakeholders. The recent corporate failures in the different parts of the world attest to the fact of failed leadership impact on every facet of the organization and even beyond the gates of these corporations. The next section discusses the strategies to adopt to prevent leadership derailment.

\section{Developing Strategies to Prevent Leadership Derailment}

Leadership derailment impacts greatly on the followers, leaders and the different facets of organizational life and activities. The different strategic options that can be utilized to prevent the consequences of the dark side of leadership in organization are presented here.

1) Executive coaching: This is defined as "the process of equipping people with the tools, knowledge and opportunities they need to develop themselves and become more effective" (Peterson, 1996:78). Executive coaching will help to develop the leaders to cope with challenges that are likely to confront them in their higher job positions. It provides opportunity for employees with high potentials to learn valuable lessons that will help them deliver results in the long-run in the organization. Thomas (2010) views the impact of executive coaching as relating to the person, to leadership performance, and to overall organizational effectiveness. Effective executive coaching that critically considers a leader's strengths and weaknesses can help in developing specific development plans for the leader and this can help prevent derailment.

2) Leadership training: This helps to foster the development of needed skills and behaviour that help the leader to perform and prevent derailment. The organization must provide varied leadership challenges and developmental assignments for the leader as these offer good learning opportunity for skill improvement. Bourne and MacKinnon (n.d) identify experiential learning which is required to help the leader to learn to accept, better understand and finally manage the underlying factors of his derailment.

3) Self-awareness: Development effort must begin with self-awareness - and this is the very first step in making the needed changes that can help prevent the leader from derailing. Self-awareness helps the people develop in their leadership roles. According to Bourne and MacKinnon (n.d) self-awareness helps a leader develop an understanding of aspects of his personality which could lead to derailment and to then proactively manage these as an important way of ensuring stable high performance and career progression.

4) Creating effective management processes and feedback: Organisations must develop effective management tools to identify early signals of derailment and address same during recruitment and selection processes. Strong management processes should be applied to promote only competent managers to higher job responsibility and not to promote people beyond their levels of competence. Providing feedback for leaders on their performance is very necessary. Furnham (2010b), notes that good leaders seek feedback from trusted, honest observers throughout their career to monitor how they are performing. Having intensive, honest and systematic feedback on performance can prevent leadership derailment. This is a vital key to any leadership development effort.

\section{Research Agenda}

Leadership derailment has received scanty treatment in the literature and therefore our knowledge of this phenomenon is still very limited. There is need for more exploratory and empirical studies to be undertaken to provide in-depth understanding of the concept.

Empirical studies should be undertaken to help clarify the relationship between the dark side of personality characteristics and leadership rating. There is need to undertake research to evaluate the dark side characteristics from multiple perspectives. There is need to carry out longitudinal studies of leaders to provide valuable perspectives on the qualities that are most closely associated with leadership derailment.

\section{Conclusion}

The large volume of leadership literature research tended to emphasize the positive aspects of leadership without 
corresponding consideration of the dark side thus limiting our knowledge about the phenomenon of leadership. Leadership derailment which implies a situation of leadership failure or career derailment has not been sufficiently researched. This is despite the fact that leadership failure is ubiquitous and the current wave of corporate failures, scandals and bankruptcies in the different parts of the world were directly associated with failed corporate leadership.

Leadership derailment which occurs because there is a disconnect between the skills and competencies of the leaders and the requirements of the new and higher job responsibility has dire consequences on followers, leaders and the organization as well as the larger social system. Some of the strategic options required to prevent leadership derailment are executive coaching, leadership training, development effort through strategic self-awareness and organization creating strong management processes. The clarion call is to improve our research offerings about the dark side of leadership to increase our knowledge and enhance our ability to effectively develop organizational leaders of tomorrow.

\section{Acknowledgements}

This paper was presented at the $20^{\text {th }}$ International Business Research Conference organized by World Business Institute, Australia, held at Novotel Trade Centre, Dubai, UAE, $4^{\text {th }}-5^{\text {th }}$ April, 2013. The author is grateful to two anonymous reviewers for their comments and the conference participants for their invaluable inputs.

\section{References}

Ashforth, B. (1994). Petty tyranny in organizations. Human Relations, 47(7), 755-788. http://dx.doi.org/10.1177/001872679404700701

Bourne, A., \& MacKinnon, R. A. (n.d.). Personality and leadership derailment. Retrieved from $\mathrm{http} / / \mathrm{www} \cdot$ talenqgroup.com

Burke, R. J. (2006). Why leaders fail: Exploring the dark side. International Journal of Manpower, 27(1), 91-100. http://dx.doi.org/10.1108/01437720610652862

Conger, J. (1990). The dark side of leadership. Organizational Dynamics, 19(2), 44-55.

Einarsen, S., Aasland, M., \& Skogstad, A. (2007). Destructive leadership behavior: A definition and conceptual model. The Leadership Quarterly, 18(3), 207-216. http://dx.doi.org/10.1016/j.leaqua.2007.03.002

Fulmer, R. M., \& Conger, J. A. (2004). Growing your company's leaders. New York: AMACOM.

Furnham, A. (2010a). The elephant in the boardroom: The cause of leadership derailment. New York: Palgrave Macmillan. http://dx.doi.org/10.1057/9780230281226

Furnham, A. (2010b). When leaders lose the plot. Management Today. Retrieved June 1, 2010, from: http://www.questia.com/read/IGI-227801476/when-leaders-lose-the...

Glaso, L., Einarsen, S., Mathiesen, S. B., \& Skogstad, A. (2010). The dark side of leaders: A representative study of interpersonal problems among leaders. Scandinavian Journal of Organizational Psychology, 2(2), $3-4$.

Henderson, K. D. (2010). Leadership derailment: Characteristics that undermine your success. Retrieved from http://poimena.com/leadership-derailment-characteristics-that-under

Higgs, M. (2009). The good, the bad and the ugly: Leadership and narcissism. Journal of Change Management, 9(2), 165-178. http://dx.doi.org/10.1080/14697010902879111

Hogan, R. (1994). Trouble at the top: Causes and consequences of managerial incompetence. Consulting Psychology Journal: Practice and Research, 46(1), 9-15. http://dx.doi.org/10.1037/1061-4087.46.1.9

Hogan, R., \& Kaiser, R. B. (2005). What we know about leadership. Review of General Psychology, 9(2), 169-180. http://dx.doi.org/10.1037/1089-2680.9.2.169

Hogan, R., Raskin, R., \& Fazzini, D. (1990). The dark side of charisma. In K. E. Clark \& M. B. Clark (Eds.), Measures of Leadership. Greensboro, NC: Centre for Creative Leadership.

Inyang, B. J. (2004). Management theory: Principles and practices (2nd ed.). Calabar: Merb Publishers.

Jones, J. W., \& Lewis, B. O. (2005). Assessing leaders to head off executive derailment. Paper presented at IPAT's "Strategic Talent Management Briefing", Chicago, IL. Retrieved November 17, 2005, from http//www.ipat.com/siteCollelctionDocuements/pdf/wp-hoed.pdf

Leslie, J. B., \& Van Velsor, E. (1996). A look at derailment today: North America and Europe. Greensboro, NC: 
Centre for Creative Leadership.

Mackie, D. (2008). Leadership derailment and psychological harm. Psych, Australian Psychological Society, April, 1-4. Retrieved from http://www.psychology.org.au/inpsych/derailment

McGraw-Hill Answers. (n.d.). The dark side of leadership. Retrieved from http://answers.mheducation.com/

McGregor, J. (2005). Gospels of failures. Fast Company Magazine, 91, 1. Retrieved from $\mathrm{http} / / \mathrm{www}$.fastcompany.com/52512/gospels-failure

Padilla, A., Hogan, R., \& Kaiser, R. (2007). The toxic triangle: Destructive leaders, susceptible followers and

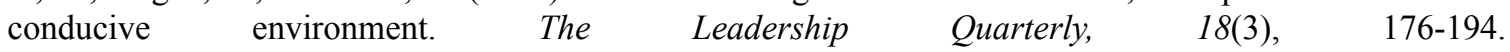
http://dx.doi.org/10.1016/j/leaqua.2007.03.001

Peterson, D. B. (1996). Executive coaching at work: The art of one-on-one change. Consulting Psychology Journal: Practice and Research, 48(2), 78-86. http://dx.doi.org/10.1037/1061-4087.48.2.78

Pienaar, J. W. (2011). What lurks beneath leadership ineffectiveness? A theoretical overview. African Journal of Business Management, 5(26), 10629-10633.

Ready, D. A. (2005). Is your company failing its leaders? Business Strategy Review, 16(4), 21-25. http://dx.doi.org/10.1111/j.0955-6419.2005.00375.x

Schilling, J. (2009). From ineffectiveness to destruction: A qualitative study of the meaning of negative leadership. Leadership, 5(1), 102-128. http://dx.doi.org/10.1177/1742715008098312

Slattery, C. (2009). The dark side of leadership: Troubling times at the top. Retrieved from $\mathrm{http} / /$ www.semannslattery.com/file_download/156

Thomas, R. E., \& Pirtle, J. (2010). Developing leaders: An analysis of efficacy of executive coaching. Leadership \& Organizational Management Journal, 3, 106-112.

Wan, K. E. (2011). Understanding managerial derailment. Ethos, 9, 1-4. Retrieved from http://www.cscollege.gov.sg/knowledge/Ethos/IssuesJune2011/pag.../

Webber, M. (1998). Why and how successful leaders get derailed. Retrieved from http://www.leadershipletters.com/1998/07/07/why-and-how-successful

\section{Copyrights}

Copyright for this article is retained by the author(s), with first publication rights granted to the journal.

This is an open-access article distributed under the terms and conditions of the Creative Commons Attribution license (http://creativecommons.org/licenses/by/3.0/). 